\title{
METHOD OF FORMATION OF 2-3 TRAILED ROAD TRAINS FOR TRANSPORT OF AGRICULTURAL PRODUCTS BY MILITARY DEPARTMENTS
}

\author{
O. M. Zagursky, A. P. Andriyevsky, B. S. Marchenko
}

National University of Life and Environmental Sciences of Ukraine. Ukraine.

Speciality of article: 275 - transport technologies (by road).

Corresponding author: zagurskiy_oleg@ukr.net.

Article history: Received - January 2020, Accepted-April 2020.

Bibl. 7, fig. 6, tabl. 0.

Abstract. The use of auto trains of material support shows that the loading and unloading process, the attachment of loaded trailers to the tractor requires some time, effort and resources. In addition, experience in the use of subdivisions agricultural cargo indicates the need for additional time, effort and resources when attaching loaded trailers to tractor units when the weight of the load does not allow one driver to rotate and direct freely the triangle of the front axle of the trailer with the engagement ring to the traction-coupling device of the tractor

The article describes the possibility of reducing the complexity rigging and coupling of loaded trailers to tractors at places of loading and unloading of agricultural products through the use of advanced coupling equipment. The process of empirical research proved the possibility of increasing efficiency transportation of agricultural goods through the use of a patented technical tool.

Use of the offered vehicles of the domestic manufacturer with traction coupling devices of the proposed sample and rigging equipment will allow you to perform lifting work with a smaller number of cargo teams, that will not only reduce the complexity of the rigging work, but also to save and spend the time, it takes overcoming obstacles by these trains and repairing damaged vehicles.

The proposed traction-coupling device will allow the trailer to be towed to the tractor by one driver. In this case, the advanced traction-coupling device has low material consumption and cost. It can be improved directly at any repair shop of automotive equipment or vehicle base.

Key words: road train, efficiency, cargo equipment, traction device, traction coupling device.

\section{Introduction}

Experience in the use of auto trains of material support shows that the loading and unloading process, the attachment of loaded trailers to the tractor requires some time, effort and resources.
At the same time in the places of loading and unloading of transport freight commands are applied at the rate of about 2-6 persons for each unit of the auto train.

\section{Formulation of problem}

To transport agricultural products from one machine with a trailer to another, freight teams of 6-8 people are required for each auto train.

The process of attaching loaded auto trailers requires the use of personnel of about 2-4 people for each trailer.

In these cases, a considerable amount of time is spent and the forces of the cargo teams to carry out the work in question.

In addition, the formation of freight teams will cause additional time needed for other activities that are needed for other production processes, which may adversely affect their agricultural production as a whole.

\section{Analysis of recent research results}

The order of carrying out of lifting works during transportation of agricultural products is quite widely publicized in the works of scientists [1-7].

However, aspects of reducing time and reducing numbers loaders - riggers required for implementation rigging and coupling works remain insufficiently disclosed.

In addition, problematic issues do not lose their relevance related to the development of recommendations to reduce complexity loading and unloading, rigging works, reducing their time using advanced rigging and coupling equipment.

\section{Purpose of research}

The purpose of the study is to investigate the feasibility and feasibility of using advanced tested rigging and traction equipment to reduce the complexity of rigging and trailing work, reducing their time spent. 


\section{Results of research}

Experience in carrying out lifting works testifies that these works are carried out by means of hoisting machines. But in the case of subdivisions of the trucking unit in different directions their number may not be sufficient to carry out cargo work, which will result in the use of cargo teams separated from the consignee. In the absence of such teams, the time, effort and resources of the trucking units will be spent. In addition, experience in the use of subdivisions agricultural cargo indicates the need for additional time, effort and resources when attaching loaded trailers to tractor units when the weight of the load does not allow one driver to rotate and direct freely the triangle of the front axle of the trailer with the engagement ring to the traction-coupling device of the tractor.

With limited time to meet the needs of consumers in the timely delivery of agricultural products to consumers, there is a need reduction of term of rigging and coupling works. One way to resolve issues that may arise is there are improvements in the delivery of agricultural produce rigging and traction equipment of machines. For use as a tractor for the operation of agricultural enterprises it is advisable to involve cars of domestic manufacturer.

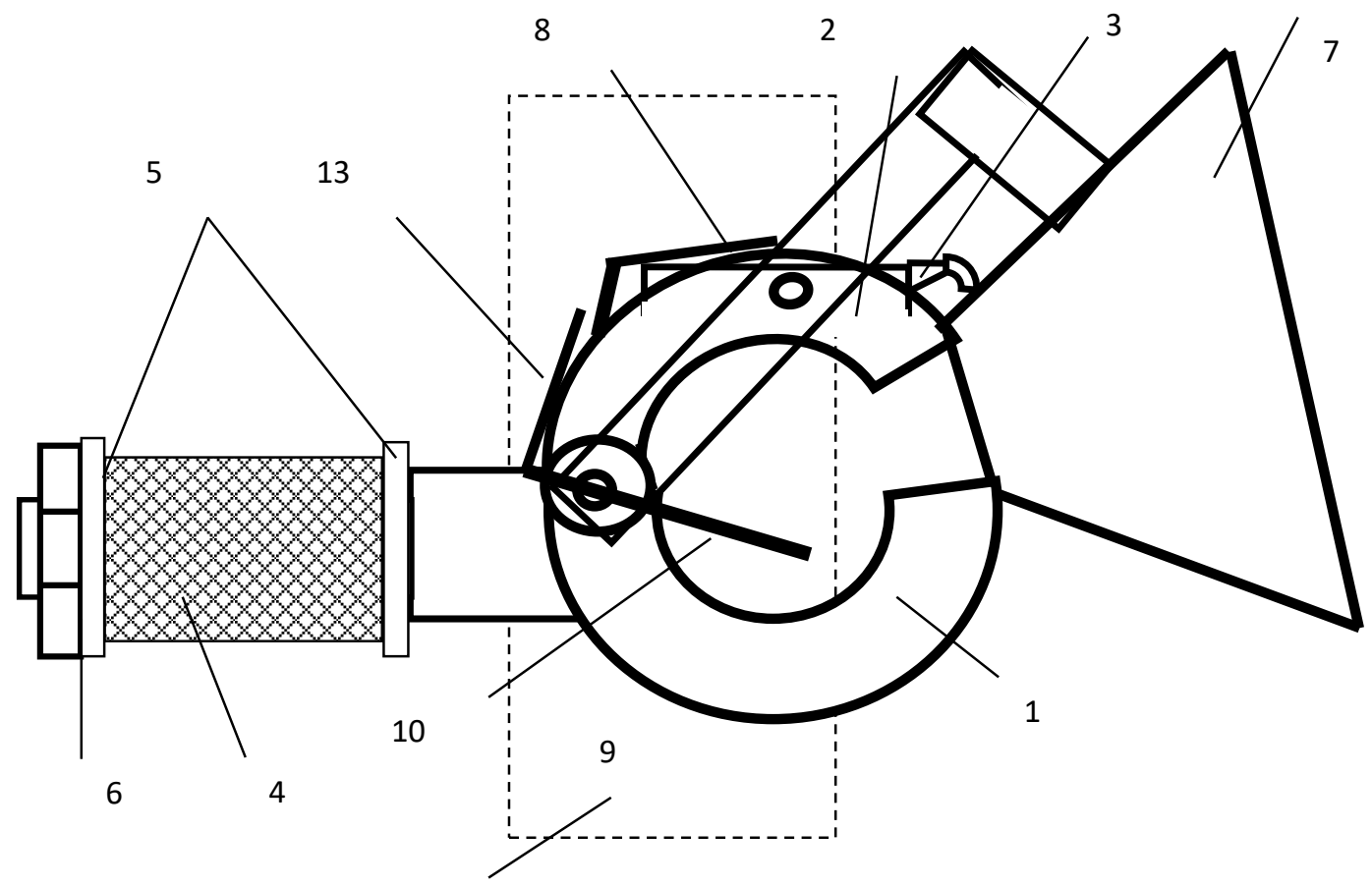

Fig. 1. Traction and coupling device (view from working position).

Source: Compiled by the authors

5

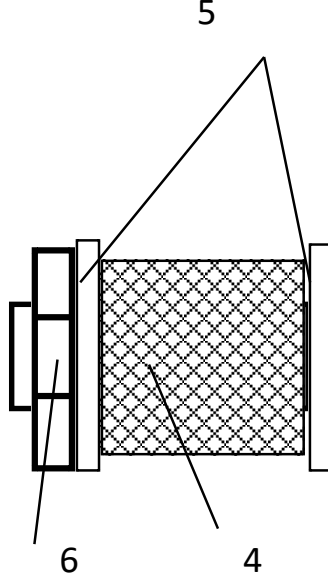

8

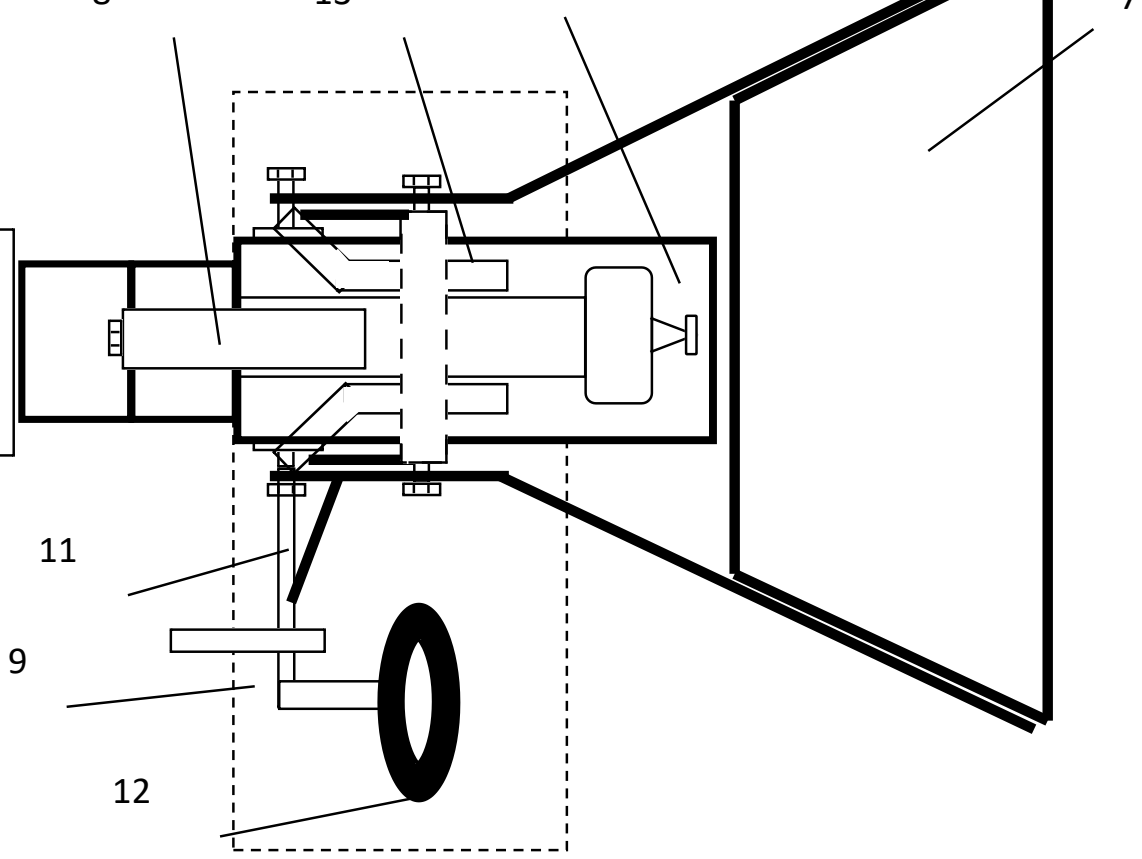

Fig. 2. Traction and coupling device (top view of working position).

Source: Compiled by the authors 
Domestic manufacturer can produce tractors with hydraulic crane boom which are appropriate to complete with slings, metal ropes and pallets and apply in agricultural transportation departments to provide lifting work that will ensure a quick overload of containers (packages) with agricultural products for temporary storage areas or to adjacent vehicles, and from them to motor vehicles.

Technological operations during the execution of rigging works. will drive one driver using the crane boom control levers. Use of the considered rigging equipment will save time and will not require the expense of the physical forces of the cargo teams to create additional technical conditions for rigging works related to cargo that has large dimensions.

Unlike existing traction - hooking devices, to reduce the complexity and reduce the hitch time of a loaded trailer. it is proposed to use an improved traction hooking device.

The traction and coupling device is structurally contained (Fig. 1;2) forged hook with rod 1, forging hook for hook 2 , retaining $\operatorname{dog} 3$, rubber elastic buffer 4 , two thrust washers 5 , nut 6 , guide sleeve 7 , elastic bar 8 of the locking of the locking $\operatorname{dog} 3$, a mechanism for controlling the engagement 9, containing the lever tracking engagement 10 , clutch control rod 11, clutch control beacon 12 , elastic bar 13 forged latch forged hook 2 .

Novelty of technical solution of design, is that it is additionally implemented in the construction of the guide casing 7, elastic bar 8 fixation of the locking dog 3 , gear control mechanism 10, containing the lever tracking gear 1 , clutch control thrust 11, engagement control beacon 12 , elastic bar for fixing the forging of the forged hook.

The use of added components reduces the complexity of the work and reducing the time of engagement of the loaded trailer to the tractor.

Before using the traction device (Fig. 3; 4) mounted on a forged hook latch 2 elastic bar 8 fixation of the locking dog 3 is bent locking $\operatorname{dog} 3$ is removed from the position of the stopper, mounted on levers tracking engagement 9 elastic bar 13 of the locking latch of the forged hook 2 is folded the forged hook 2 latch is pulled open, depending on the open position of the latch forged hook 6 traction control traction 11 moves the beacon to control the engagement 12 through the engagement lever 10 gear control mechanism 9 and informs the driver through the rearview mirror about the open position of the traction device.

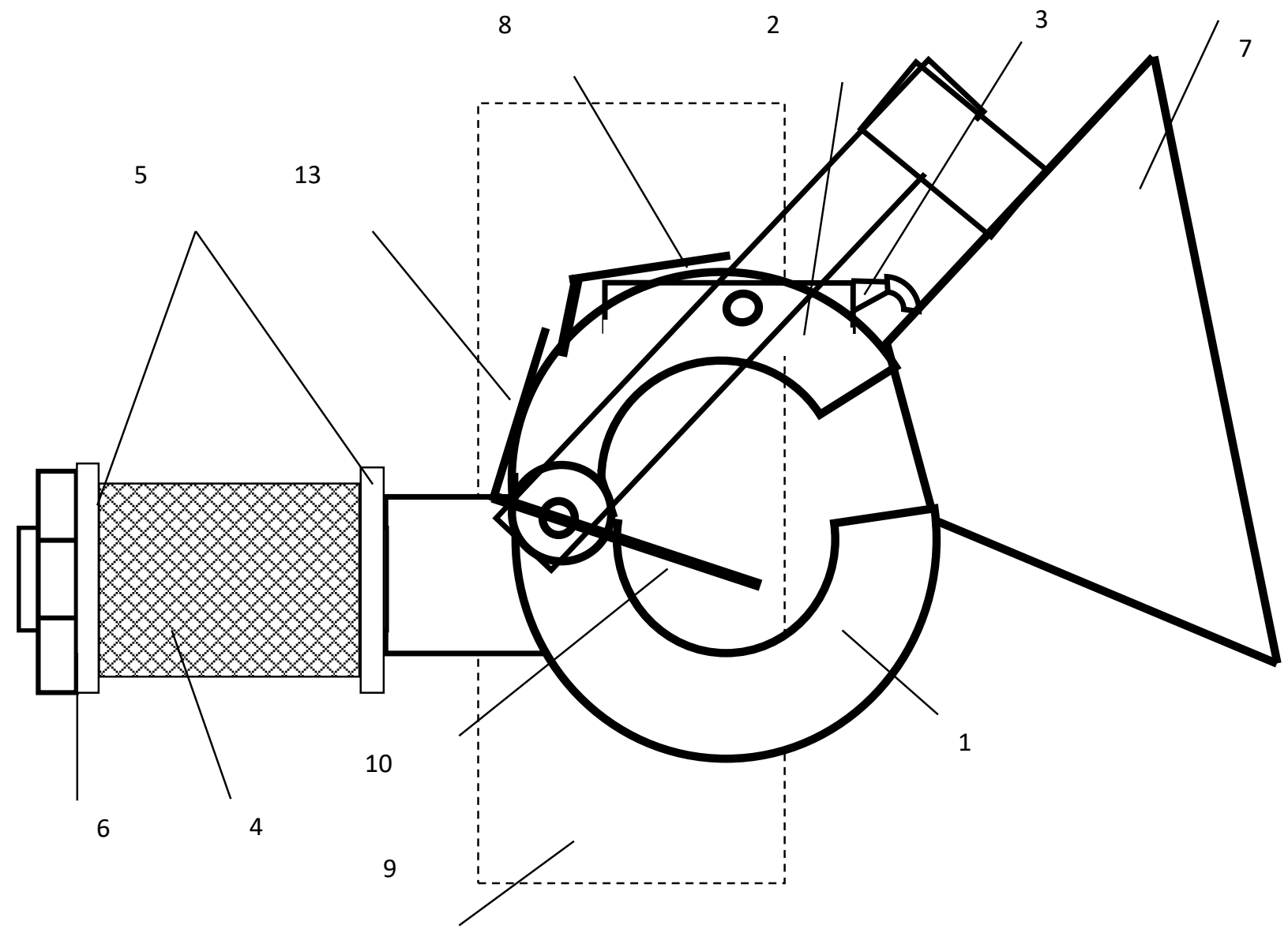

Fig. 3. Traction coupling device (side view of the coupling position). Source: Compiled by the authors

The tractor moves backwards to the trailer as follows to the direction of movement of the left rear wheel approximately coincided with the direction of the position left wheel trailer In this case, the guide casing 7 , fastened to the forged hook hook 2 , directs the trailer engagement ring to the forged hook with 
rod 1, when the trailer coupling ring enters the forged hook with rod 1 lever tracking engagement 10 pulls the spring bar 13 forged hook hooks 2 and under the action of the force of the elastic strap 13 the forged hook 2 latch will close.
After the hook latch is completely closed 2 elastic straps 8 fixation of the locking dog 3 securely locks the lock dog 3 forged hook latches 2 .

The considered traction and coupling device allows to attach the trailer to the tractor by the force of one driver and reduce the complexity of technological work when hitching.

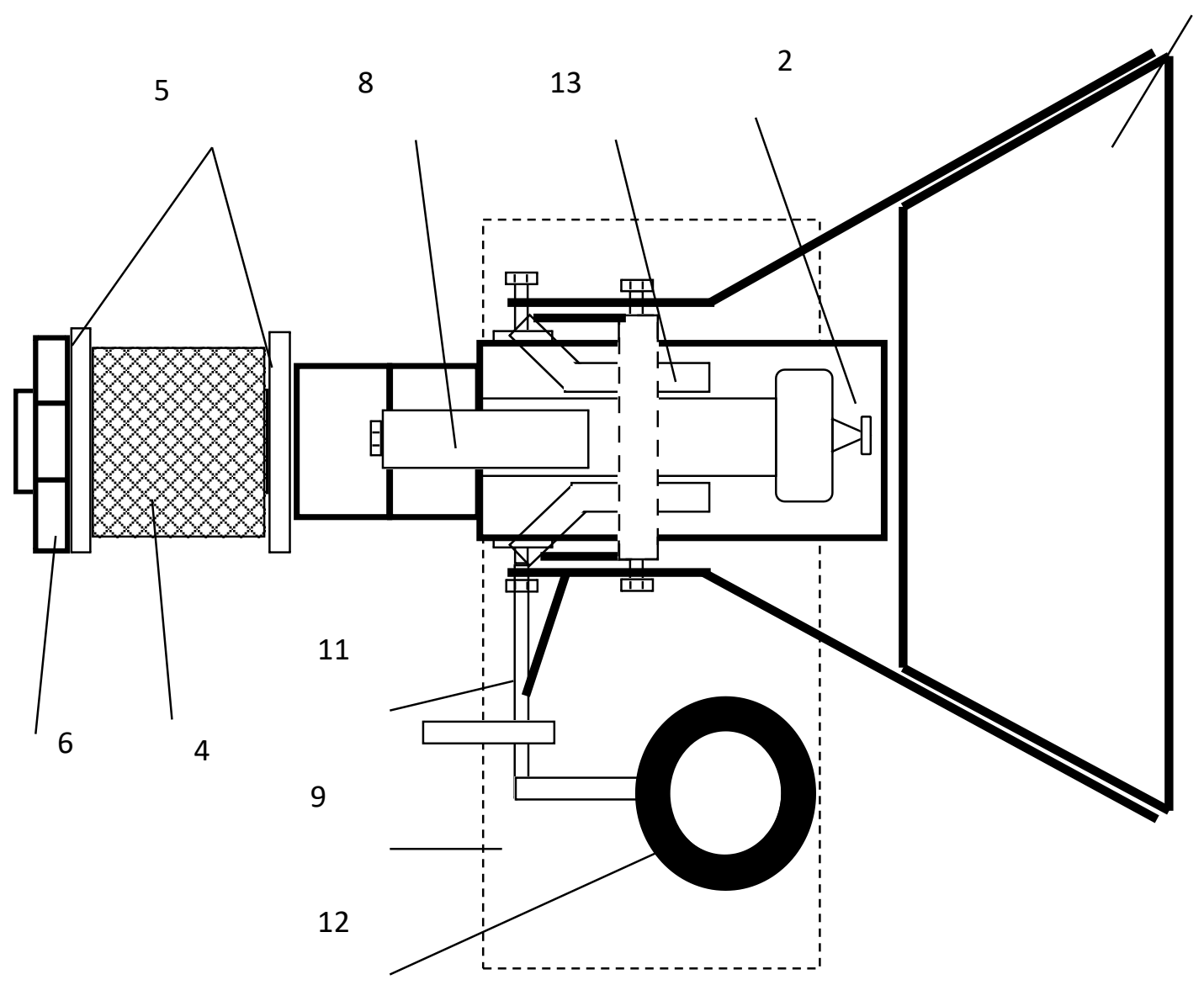

Fig. 4. Traction and coupling device (top view of the coupling position).

Source: Compiled by the authors

The advanced traction and coupling device has a low material capacity and the cost of manufacture. It can be improved directly in any organ repair automotive engineering or automotive base.

It is known that the total duration of unloading and unloading and rigging works $\mathrm{T}_{\mathrm{tr}}$ consists of individual time events

$$
T_{t r}=\sum_{i}^{n_{c o m}} t_{i}
$$

where $\mathrm{i}-$ the unloading and loading number and a rigging event;

$\mathrm{n}_{\mathrm{com}}$ - the number of loading and unloading and lifting operations and events during transport;

$\mathrm{t}_{\mathrm{i}}$ - time required for each event, min. or hour.;

or based on (1);

$$
\mathrm{T}_{\mathrm{tr}}=\mathrm{t}_{1}+\mathrm{t}_{2}+\mathrm{t}_{3}+\mathrm{t}_{4}
$$

In Fig. 5 shows a typical schedule for the implementation of transport activities during the transport of goods for agricultural purposes.

The tractor moves backwards to the trailer as follows to the direction of movement of the left rear wheel approximately coincided with the direction of the position left wheel trailer In this case, the guide casing 7 , fastened to the forged hook hook 2, directs the trailer engagement ring to the forged hook with rod 1 , when the trailer coupling ring enters the forged hook with rod 1 lever tracking engagement 10 pulls the spring bar 13 forged hook hooks 2 and under the action of the force of the elastic strap 13 the forged hook 2 latch will close.

After the hook latch is completely closed 2 elastic straps 8 fixation of the locking dog 3 securely locks the lock dog 3 forged hook latches 2. The considered traction and coupling device allows to attach the trailer to the tractor by the force of one driver and reduce the complexity of technological work when hitching. 


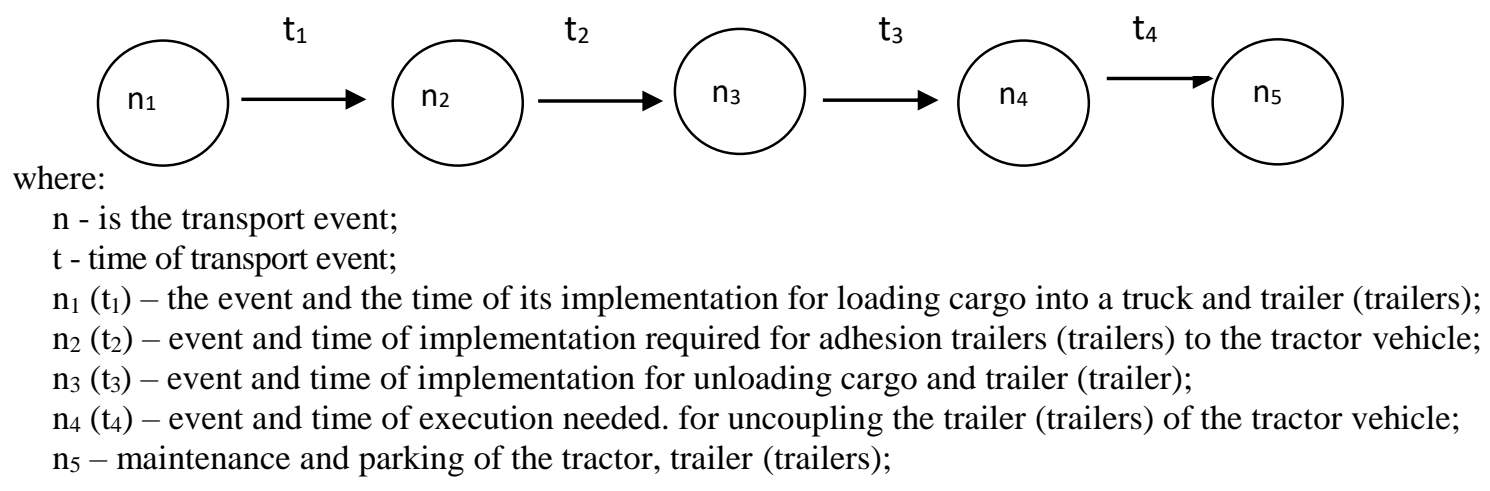

Fig. 5. Figure spending time to implement transport measures during the transport of goods for agricultural purposes.

Source: Compiled by the authors

As can be seen from Fig. 6, as compared to transport variant A using a patented traction device transport option B involves much less time and staff,

The time required for transport with the use of a traction coupling device: considering (2) can be described as follows:

$\operatorname{Ttr}=\mathrm{t}_{1}+\mathrm{t}_{2}+\mathrm{t}_{3}+\mathrm{t}_{4} \gg \mathrm{T}_{\operatorname{tr} \mathrm{AT}}=\mathrm{t}_{1}+\mathrm{t}_{2} / 2+\mathrm{t}_{3} / 2+\mathrm{t}_{4}$

$$
\mathrm{T}_{\mathrm{tr}} \gg \mathrm{T}_{\mathrm{tr}} \mathrm{AT}
$$

In this case (3) time t3 (time of unloading of cargo and trailer (trailers)) as well as the time t5 (the time of maintenance and parking of the tractor, trailer (s)) due to the structural features of the traction coupling device is halved.

or

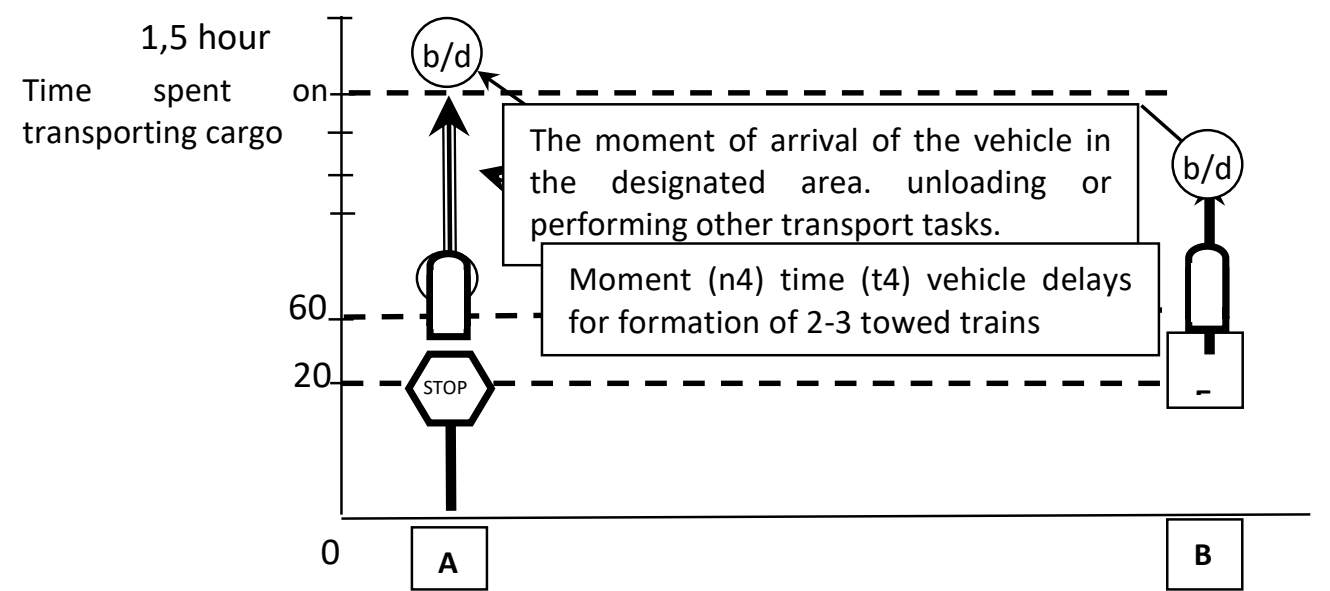

Legend:

A - duration ( $\mathrm{Ti}$ ) of carriage of goods during transportation without the use of traction coupling device;

B - duration ( $\mathrm{Ti}$ ) of carriage of goods during transportation using a coupling device:

- a vehicle with a crew;

STOP - moment (n4) of time (t4) of vehicle delay for formation of 2-3 towed trains;

(4) - moment of time $\left(t_{i}\right)$ of beginning of continuation of movement of the vehicle;

b/d - the moment the vehicle arrives at the designated unloading area or performing other transport tasks.

Fig. 6. Duration of transportation during transportation of agricultural goods to consumers.

Source: Compiled by the authors

In addition, the practice of using a traction device avoids downtime and lost time stop t4 (time required to uncouple trailer (s) from tractor). Thus in the process of empirical research proved the possibility of increasing efficiency transportation of agricultural goods through the use of a patented technical tool. Total length of cargo transportation Трз thus considerably reduced and recorded as follows:

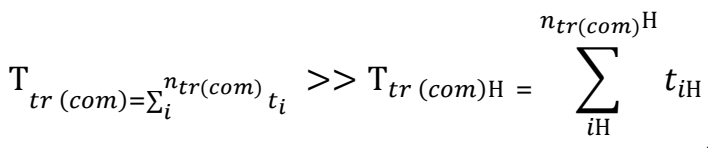


Therefore, the trucking unit will perform the transport task more effectively.

\section{Conclusions}

1. Use of the offered vehicles of the domestic manufacturer with traction coupling devices of the proposed sample and rigging equipment will allow you to perform lifting work with a smaller number of cargo teams, that will not only reduce the complexity of the rigging work, but also to save and spend the time, it takes overcoming obstacles by these trains and repairing damaged vehicles.

2. The proposed traction-coupling device will allow the trailer to be towed to the tractor by one driver. In this case, the advanced traction-coupling device has low material consumption and cost. It can be improved directly at any repair shop of automotive equipment or vehicle base.

3. The direction of further research may be developing recommendations for improving the structure and methods of application of vehicles through the introduction of other equipment.

\section{References}

1.Burdzik R., Cieśla M., Sładkowski A., (2014). Cargo loading and unloading efficiency analysis in multimodal transport. Intermodal Transport Review Submitted: Aug. 12, 2013 Approved: July 8. 323-327.

2.Gollin D., Rogerson R. (2014). Productivity, transport costs and subsistence agriculture. Journal of Development Economics Volume 107, March 2014, 3848.

3.Damania R., Berg C., Russ J., Barra F., Nash John, Ali R. (2017). Agricultural Technology Choice and Transport. American Journal of Agricultural Economics, Volume 99, Issue 1, January 2017, 265-284.

4.Feng J. (2014). Discussion on the Promotion of Drop-and-Pull Transport Organization Mode of Shandong Province Road Logistics Enterprises 10th Asia Pacific Transportation Development Conference May 25-27, 2014. Beijing, China.

5.Hübner A., Ostermeier M. (2019). A MultiCompartment Vehicle Routing Problem with Loading and Unloading Costs Transportation Science Vol. 53, No. 1 January-February. 282-300.

6.Shepelev V., Almetova Z. , Shepelev S., Issenova O. (2018). Optimization of the Operating Parameters of Transport and Warehouse Complexes. Transportation Research Procedia. Volume 30, 236-244

7.Stella Maris Huertas, Rick E. A. M. Kempener, Frank J. C. M. van Eerdenburg (2018). Relationship between Methods of Loading and Unloading, Carcass Bruising, and Animal Welfare in the Transportation of Extensively Reared Beef Cattle Animals Open Access Journal 2018 Jul; 8(7): 119.

\section{Список літератури}

1.Burdzik R., Cieśla M., Sładkowski A., Cargo loading and unloading efficiency analysis in multimodal transport. Intermodal Transport Review Submitted: Aug. 12, 2013 Approved: July 8. 2014. P. 323-327.

2. Gollin D., Rogerson R. Productivity, transport costs and subsistence agriculture. Journal of Development Economics Volume 107, March 2014, P. 38-48.

3.Damania R., Berg C., Russ J., Barra F., Nash John, Ali R. Agricultural Technology Choice and Transport. American Journal of Agricultural Economics, Volume 99, Issue 1, January 2017, P. 265-284.

4. Feng J. Discussion on the Promotion of Drop-andPull Transport Organization Mode of Shandong Province Road Logistics Enterprises 10th Asia Pacific Transportation Development Conference May 25-27, 2014. Beijing, China.

5.Hübner A., Ostermeier M. A Multi-Compartment Vehicle Routing Problem with Loading and Unloading Costs Transportation Science. 2019. Vol. 53, No. 1 January-February. P. 282-300.

6.Shepelev V., Almetova Z. , Shepelev S., Issenova O. Optimization of the Operating Parameters of Transport and Warehouse Complexes. Transportation Research Procedia. 2018. Volume 30, P. 236-244

7.Stella Maris Huertas, Rick E. A. M. Kempener, Frank J. C. M. van Eerdenburg. Relationship between Methods of Loading and Unloading, Carcass Bruising, and Animal Welfare in the Transportation of Extensively Reared Beef Cattle Animals Open Access Journal 2018 Jul; 8(7): P. 119.

\section{СПОСІБ ФОРМУВАННЯ 2-3 ПРИЧЕПНИХ АВТОПОЇЗДІВ ДЛЯ ПЕРЕВЕЗЕННЯ \\ СІЛЬСЬКОГОСПОДАРСЬКОЇ ПРОДУКЦІЇ ВІЙСЬКОВИМИ ПІДРОЗДІЛАМИ \\ О. М. Загурський, А. П. Андрієвський, Б. С. Марченко}

Анотація. Досвід застосування автопоїздів матеріального забезпечення показує, що завантажувально-розвантажувальний процес, зачеплення завантажених причепів до тягачів потребують витрачання певного часу, сил та засобів. Крім того, підвезення сільськогосподарських вантажів потребує додаткового часу, сил та засобів під час зачеплення завантажених причепів до автомобілівтягачів, коли вага вантажу не дозволяє одному водію вільно повернути та спрямувати трикутник передньої вісі причепу з зачіпним кільцем до тягово-зачіпного пристрою тягача.

У статті викладено можливість зниження трудомісткості проведення такелажних робіт та зачеплення завантажених причепів до тягачів у місцях завантаження та розвантаження сільськогосподарської продукції за рахунок застосування удосконаленого зачіпного обладнання. У процесі емпіричних досліджень доказано можливість підвищення ефективності транспортування вантажів сільськогосподарського призначення за рахунок застосування запатентованого технічного засобу. 
Використання пропонованих транспортних автомобілів вітчизняного виробника 3 тяговозачіпними пристроями запропонованого зразка i такелажним обладнанням дозволить виконувати такелажні роботи меншою чисельністю вантажних командах, що дозволить не тільки знизити трудомісткість такелажних робіт, а i зберегти та раціонально витратити час, необхідний для подолання перешкод цими автопоїздами та відновлення пошкоджених транспортних засобів.

Запропонований тягово-зачіпний пристрій дозволить причепити причіп до тягача силою одного водія. При цьому удосконалений тягово-зачіпний пристрій має невисокі матеріалоємність і вартість виготовлення. Він може бути удосконалений безпосередньо в будь-якому ремонтному органі автомобільної техніки чи автомобільної бази.

Ключові слова: автопоїзд, ефективність, вантажне обладнання, тягово-зачіпний пристрій.

\section{СПОСОБ ФОРМИРОВАНИЯ 2-3 ПРИЦЕПНЫХ АВТОПОЕЗДОВ ДЛЯ ПЕРЕВОЗКИ СЕЛЬСКОХОЗЯЙСТВЕННОЙ ПРОДУКЦИИ ВОЕННЫМИ ПОДРАЗДЕЛЕНИЯМИ О. Н. Загурский, А. П. Андриевский, Б. С. Марченко}

Аннотация. Опыт применения автопоездов материального обеспечения показывает, что погрузочно-разгрузочный процесс, зацепления загруженных прицепов к тягачfv потребует расходования определенного времени, сил и средств. Кроме того, подвоз сельскохозяйственных грузов требует дополнительного времени, сил и средств при зацепления загруженных прицепов к автомобилямтягачей, когда вес груза не позволяет одному водителю свободно вернуть и направить треугольник передней оси прицепа с зацепными кольцом к тяговозацепным устройствам тягача.

В статье изложена возможность снижения трудоемкости проведения такелажных работ и зацепления загруженных прицепов к тягачам в местах загрузки и разгрузки сельскохозяйственной продукции за счет применения усовершенствованного зацепного оборудования. В процессе эмпирических исследований доказано возможность повышения эффективности транспортировки грузов сельскохозяйственного назначения за счет применения запатентованного технического средства.

Использование предлагаемых транспортных автомобилей отечественного производителя с тяговозацепными устройствами предложенного образца и такелажным оборудованием позволит выполнять такелажные работы меньшей численностью грузовых командах, что в свою очередь не только снизит трудоемкость такелажных работ, а и сохранит и рационально использует время, необходимое для преодоления препятствий этими автопоездами а также на восстановление поврежденных транспортных средств.

Предложенное тягово-зацепное устройство позволит прицепить прицеп к тягачу силой одного водителя. При этом усовершенствованное тягово- зацепное устройство имеет невысокую материалоемкость и стоимость изготовления. При этом его еще можно усовершенствовать непосредственно в любом ремонтном органе автомобильной техники или автомобильной базы.

Ключевые слова: автопоезд, эффективность, грузовое оборудование, тягово-зацепное устройство.

О. М. Загурський ORCID 0000-0002-5407-8466.

А. П. Андрісвський ORCID 0000-0003-1896-4011.

Б. С. Марченко ORCID 0000-0003-0076-373X. 
